\title{
Behaviour of micropiles in heterogeneous coarse soils
}

1 Diego Bellato MSc, PhD

Project Manager, Department of International Project and Services, Bauer Spezialtiefbau GmbH, Schrobenhausen, Germany; formerly University of Padova (Corresponding author: diego.bellato@bauer.de)

2 Sandro D'Agostini MSC, PEng

Managing Director, Venetian Transportation Authority, Sedico, Italy
3 Simonetta Cola MSc, PhD

Associate Professor, Department ICEA, University of Padova, Padova, Italy

4 Paolo Simonini MSc, $\mathrm{PhD}$

Full Professor, Department ICEA, University of Padova, Padova, Italy
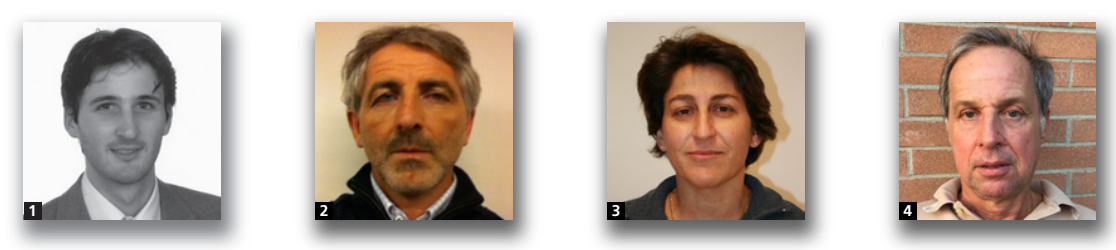

This paper reports on an experimental investigation on the behaviour of small-diameter piles, commonly referred to as micropiles. This particular type of deep foundation is frequently used in many barely accessible Italian mountainous areas, often characterised by complex ground profiles composed of mixtures of coarse soils with some fine matrix elements including cobbles and large-diameter boulders. In such ground conditions, the lack of reliable site and laboratory geotechnical investigations providing an accurate soil mechanical description and conservative approaches for micropile design often lead to significant underestimation of the vertical ultimate load. In order to improve micropile design in such geological contexts, a new field trial investigation involving tension and compression load tests on micropiles up to failure was set up in a selected test site located in the Italian alpine region. From interpretation of the load tests carried out so far, the reliability of commonly used calculation methods for estimating bearing capacity is discussed. As a result, a new approach for a more suitable calculation of the mobilised shaft and base resistance of micropiles bored in highly coarse soils is tentatively proposed.

\section{Notation}

C Chin's coefficient determined by best-fit procedure $(\mathrm{mm} / \mathrm{kN})$

$D \quad$ diameter of micropile (mm)

$D_{\mathrm{s}} \quad$ effective diameter of pile after grouting phase $(\mathrm{mm})$

$I_{\mathrm{D}} \quad$ density index of in situ soil (\%)

$K \quad$ horizontal earth pressure coefficient

$K_{0} \quad$ coefficient of earth pressure at rest

$L \quad$ length of micropile (m)

$L_{\mathrm{s}} \quad$ bond length of micropile (m)

$N_{1,60} \quad$ number of blows of standard penetration test (SPT) test under a vertical effective stress of $100 \mathrm{kPa}$ corrected to $60 \%$ of theoretical free-fall hammer energy

$N_{\mathrm{q}} \quad$ bearing capacity factor

$n \quad$ Chin's coefficient determined by best-fit procedure $\left(\mathrm{kN}^{-1}\right)$

$p^{\prime} \quad$ mean overburden effective stress $(\mathrm{kPa})$

$p_{\mathrm{a}} \quad$ reference pressure, equal to $100 \mathrm{kPa}$

$Q \quad$ applied load during load test $(\mathrm{kN})$

$Q_{\mathrm{b}, \mathrm{u}}^{\beta} \quad$ end bearing capacity of micropile in coarse soils from static formulae $(\mathrm{kN})$
$Q_{\mathrm{s}, \mathrm{u}}^{\beta} \quad$ shaft friction of micropile in coarse soils from static formulae $(\mathrm{kN})$

$Q_{\mathrm{u}} \quad$ ultimate load of micropile determined using the method of Bustamante and Doix (1985) (kN)

$Q_{\mathrm{U}, \text { Chin }} \quad$ ultimate load of micropile estimated using method of Chin (1970) $(\mathrm{kN})$

$Q_{\mathrm{U} \text {,est }} \quad$ ultimate load of micropile estimated by preliminary computations $(\mathrm{kN})$

$Q_{\mathrm{U}, \text { Hanna }}$ ultimate load of micropile estimated from method of Hanna (1987) $(\mathrm{kN})$

$Q_{\mathrm{U}, \mathrm{Test}} \quad$ ultimate load of micropile estimated from load tests $(\mathrm{kN})$

$q_{\mathrm{s}} \quad$ shaft friction mobilised at the soil-pile interface ( $\left.\mathrm{kPa}\right)$

SPT $N$ number of blows from SPT

$w \quad$ displacement measured at pile head (mm)

$w^{\prime} \quad$ net displacement of pile $(\mathrm{mm})$

$z \quad$ depth $(\mathrm{m})$

$\beta \quad$ coefficient in ' $\beta$ method' for calculation of shaft resistance of micropile

$\beta_{0} \quad$ coefficient in ' $\beta$ method' in normally consolidated soils

$\sigma_{\mathrm{v}}^{\prime} \quad$ vertical effective stress $(\mathrm{kPa})$ 


\section{$\sigma_{\mathrm{v}, \mathrm{p}}^{\prime} \quad$ vertical effective stress at pile base ( $\left.\mathrm{kPa}\right)$ \\ $\phi^{\prime} \quad$ peak angle of shearing resistance of soil (degrees) \\ $\phi_{\mathrm{m}}^{\prime} \quad$ modified angle of shearing resistance to account for possible disturbance of soil surrounding pile base due to installation (degrees)}

\section{Introduction}

In recent decades, the use of small-diameter (less than $0.3 \mathrm{~m}$ ) bored piles or micropiles has become increasingly widespread all over the world due to their ease of installation in difficult site conditions at high rates of daily production and their wide range of engineering applications such as piled foundations (Larsson and Jog, 2014), soil improvement (Ziaie Moayed and Naeini, 2012) and slope stabilisation (Juran et al., 1996). More particularly, micropiles are frequently used in many barely accessible mountainous areas in Italy, often characterised by sloping ground whose profile is composed of mixtures of coarse soils with some fine matrix elements including cobbles and large-diameter boulders. In such circumstances, the overall stability of shallow footings and other structures such as retaining walls has to be improved and micropiles represent the preferred solution to this technical problem.

Based upon their load-carrying mechanism, micropiles are classified into two types (Sabatini et al., 2005). Case 1 micropiles are elements whose capacity is mainly related to the single micropile-soil interaction mechanism. On the contrary, case 2 micropiles are networks of reticulated micropiles forming a ground modification system made of the original soil mass internally reinforced by rigid elements. It is noteworthy that case 1 micropiles are normally much more common than case 2 micropiles. According to Misra et al. (2004), more than 90\% of the micropiles installed in North America are case 1 piles.

On the basis of the grouting method and pressure used at the site, micropiles are further classified as the following (Bruce et al., 1997).

Type A micropiles are constructed by pouring grout into a drilled hole under gravity only through a tremie pipe lowered to the bottom of the borehole and gradually raised up.

- Type B micropiles are constructed by grouting the drilled hole under low pressure while the temporary steel casing of the drilling equipment is being withdrawn.

- Type $\mathrm{C}$ micropiles are constructed by injecting grout via a sleeved grout pipe and without the use of a packer at a pressure of at least $1 \mathrm{MPa}$.

- Type D micropiles are built by forcing the grout to flow under high pressure (2-8 $\mathrm{MPa}$ ) through a sleeved pipe to compress the soil around the shaft. A packer may be used inside the sleeved pipe to treat selected layers by repeated injections of grout.
Types $\mathrm{C}$ and $\mathrm{D}$ require a primary low-strength neat cement grout placed under gravity head. Type A micropiles, which are less expensive and simpler to construct, are frequently used in many civil engineering projects in the Italian alpine regions (Bellato et al., 2013).

Specific production equipment and construction techniques have been recently developed in order to increase the structural effectiveness of micropiles (Sabatini et al., 2005). However, despite several technical improvements, it is still difficult to predict the behaviour of micropiles, especially where site conditions are quite complex and characterised by heterogeneous soils formed by a chaotic and erratic mixture of gravel, sand and silt, including cobbles and boulders, as in mountainous areas. In these contexts, geotechnical investigations are normally carried out only by means of boreholes and standard penetration tests (SPTs) or super-heavy dynamic probe tests (DPSH) (EN 1997-2 (CEN, 2007)), leading to a very poor characterisation of soils.

The ultimate load of micropiles is usually estimated through well-known analytical approaches developed for mediumto large-diameter bored piles (e.g. Brown et al., 2010; Jeon, 2004) or other empirical procedures (e.g. Bustamante and Doix, 1985; Juran et al., 1999; Sabatini et al., 2005) affected by a relatively high level of uncertainty. More refined mathematical models describing the soil-micropile interaction under axial load have been recently presented and discussed in the literature (e.g. Hong and Chim, 2015; Misra and Chen, 2004; Misra et al., 2004, 2007). These methods, however, still need further validation and have not yet been incorporated in international standards or guidelines for the design of micropiles.

To better investigate the behaviour of micropiles in heterogeneous coarse soil, an experimental test site in the northeastern Italian Alps, the Listolade test site (LTS), characterised by dense alluvial and detrital mostly coarse soil, was selected. Small-diameter piles were installed and subsequently tested, both in tension and compression, up to failure of the pile-soil system.

On the basis of back-analysis of the experimental outcomes from the trial field test, the ' $\beta$ method' (e.g. Brown et al., 2010; Jeon, 2004) was tentatively modified in order to take into account the dilation effect of soil (e.g. Bolton, 1986; Schanz and Vermeer, 1996), which is quite significant in the coarse soil encountered at the LTS.

\section{Soil conditions at the LTS}

Figure 1 shows a plan view of the test site with the locations of the geotechnical investigations, which consisted of two boreholes with SPT. The installation positions of the micropiles are also shown in the figure. 
Figure 2 depicts the soil profile based on the ground investigation conducted at the LTS. The subsoil was composed of a mixture of both fluvio-glacial coarse soil, transported by a stream flowing nearby, and colluvial detrital deposits derived from the surrounding very steep rockwalls mostly made of Dolomitic rock. Underneath a thin top layer of very slightly gravelly, slightly silty sand, the soil profile presents a dense layer of sub-angular and angular shaped gravel with cobbles and boulders dispersed in a sandy and silty matrix. A mixture of medium-dense slightly silty gravelly sand was found

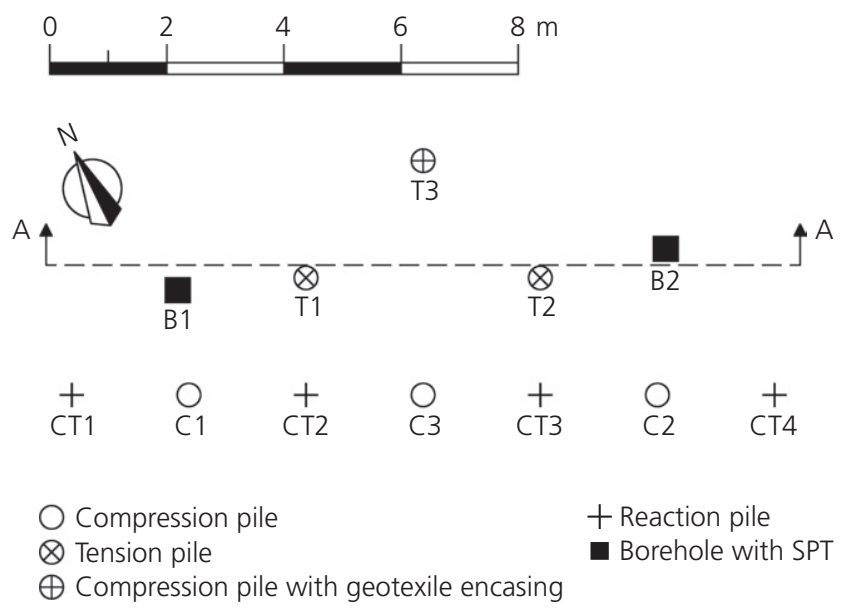

Figure 1. Location of site investigations and pile load tests starting at a depth of about 5.5-6.0 m below ground level up to the depth of interest ( $9 \mathrm{~m}$ below ground level). No groundwater table was measured in the boreholes.

The mechanical characterisation of such soils is extremely difficult and, at the LTS, the only possible site testing was SPTs. The SPT data were corrected to account for the hammer efficiency and the overburden pressure. Figure 2 shows the resulting $N_{1,60}$ values, which were found to be between 24 and 45 and, in one case, up to 77 . These outcomes were subsequently used to estimate the density index $\left(I_{\mathrm{D}}\right)$ and the angle of shearing resistance $\left(\phi^{\prime}\right)$. More specifically, the empirical correlation for gravelly soil suggested by Yoshida et al. (1988) was used to evaluate $I_{\mathrm{D}}$ whereas $\phi^{\prime}$ was evaluated according to the work of Brown et al. (2010). For the first layer, with a thickness of $0.5 \mathrm{~m}$, no SPT values were available and the corresponding mechanical parameters were tentatively assumed from geotechnical data coming from sites located near the LTS. The soil parameters are listed in Table 1. Laboratory tests were conducted to determine the particle size distribution at different depths, as shown in Figure 2.

\section{Micropile installation}

Six type A micropiles of $200 \mathrm{~mm}$ diameter were installed at the LTS (Figure 1) in order to be tested under compression and tension. Additional anchoring micropiles of $200 \mathrm{~mm}$ diameter were also created to provide adequate reactive capacity according to ASTM D1143 (ASTM, 1994).

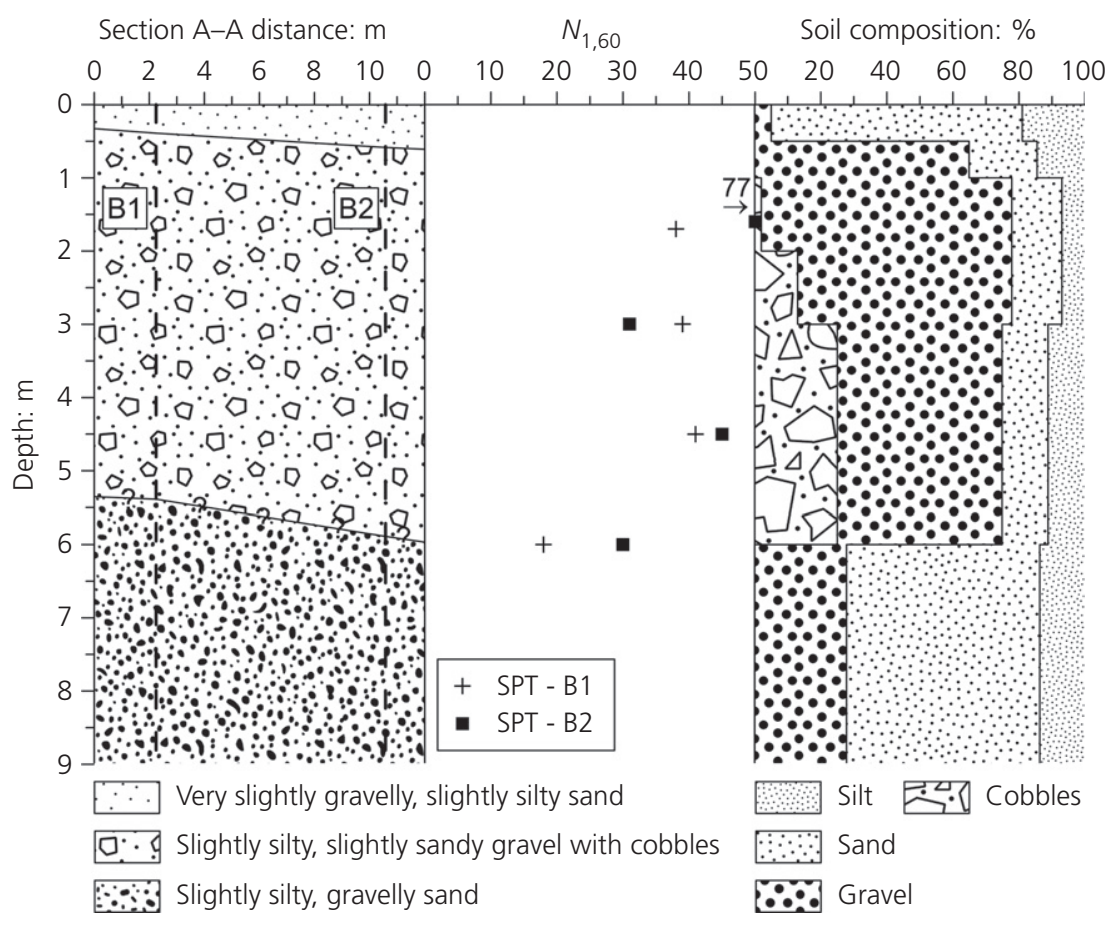

Figure 2. Results of the ground investigation campaign at the LTS 
The drill rig used at the LTS was a hydraulic rotary unit equipped with a coring diameter of approximately $200 \mathrm{~mm}$ (198 mm cutting shoe). The typical drilling technique used in the Italian alpine regions is the so-called rotary concentric percussive duplex (Sabatini et al., 2005) in which the drill rods inside the casing and the casing itself are simultaneously percussed, rotated and advanced. Compressed air was used for cleaning and removal of the spoil material during drilling.

Despite the coarse nature of the subsoil, once the designed depth (ranging from $5.2 \mathrm{~m}$ to $5.5 \mathrm{~m}$ below ground level) was achieved, the drilling bit and the casing could be withdrawn without the risk of the hole wall becoming unstable. This was possible due to the high-density state and interlocking of the deposit and likely to some cementation between the particles.

A tubular steel reinforcement $(139.7 \mathrm{~mm}$ diameter, $10 \mathrm{~mm}$ thick) was inserted in all the drilled holes corresponding to the micropiles to be tested in compression (Figure 3(a)). An additional GEWI bar of $32 \mathrm{~mm}$ diameter was placed inside the piles subjected to tension load, namely the anchor micropiles and the micropiles tested for pull-out capacity

\begin{tabular}{|c|c|c|c|c|c|c|}
\hline Layer & Description & From: m & To: $\mathrm{m}$ & $N_{1,60}$ & $\phi_{\mathrm{p}}^{\prime}:$ degrees & $I_{D}: \%$ \\
\hline 1 & Very slightly gravelly, slightly silty sand & $0 \cdot 00$ & $0 \cdot 50$ & - & 35 & 40 \\
\hline 2 & Slightly silty, slightly sandy gravel with cobbles & $0 \cdot 50$ & $5 \cdot 50-6 \cdot 00$ & $43^{a}$ & 43 & 80 \\
\hline 3 & Slightly silty, gravelly sand & $5 \cdot 50-6 \cdot 00$ & 8.00 & $27^{a}$ & 39 & 60 \\
\hline
\end{tabular}

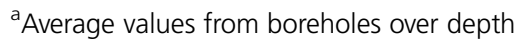

Table 1. Geotechnical characterisation of the subsoil at the LTS

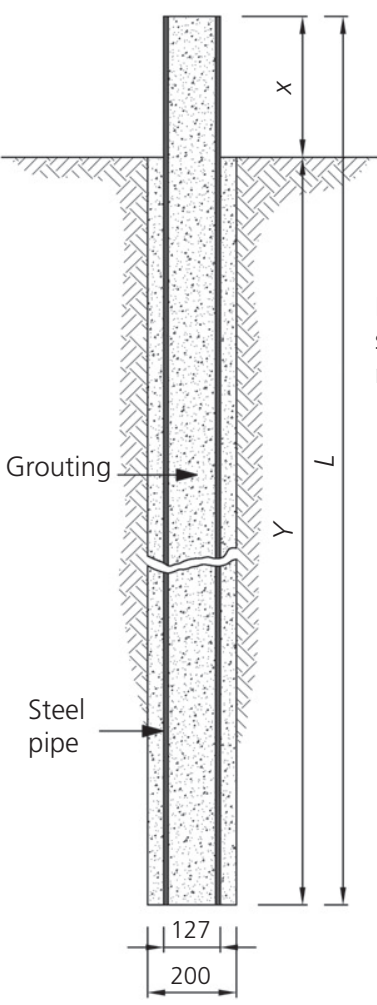

(a)

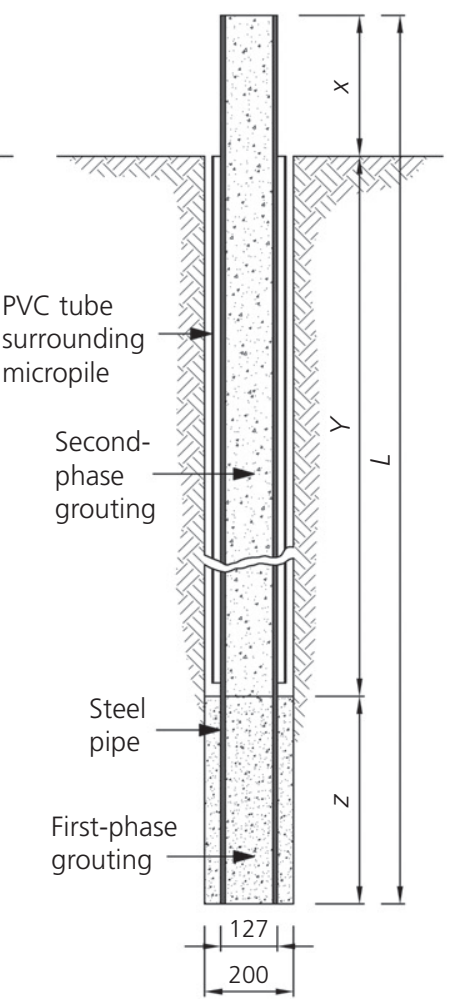

(b)

Figure 3. Longitudinal sections of the types of micropile installed at the LTS: (a) micropile tested in compression; (b) special micropile $\mathrm{C} 3$ tested in compression; (c) micropile tested in tension;

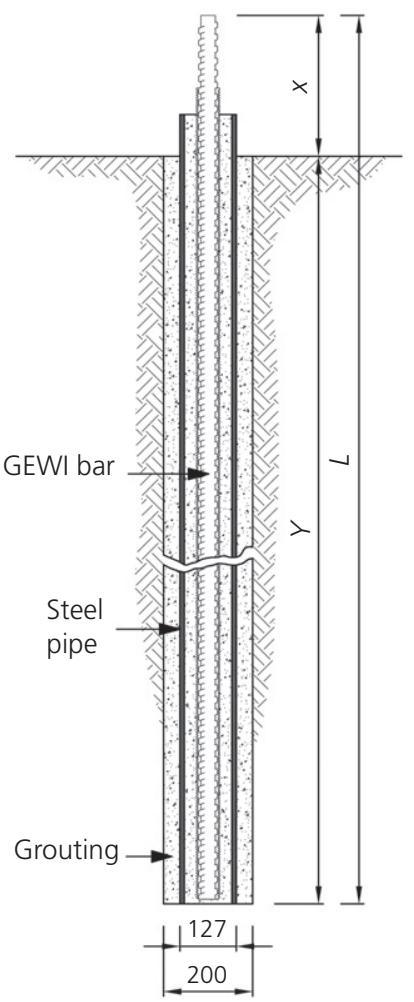

(c)

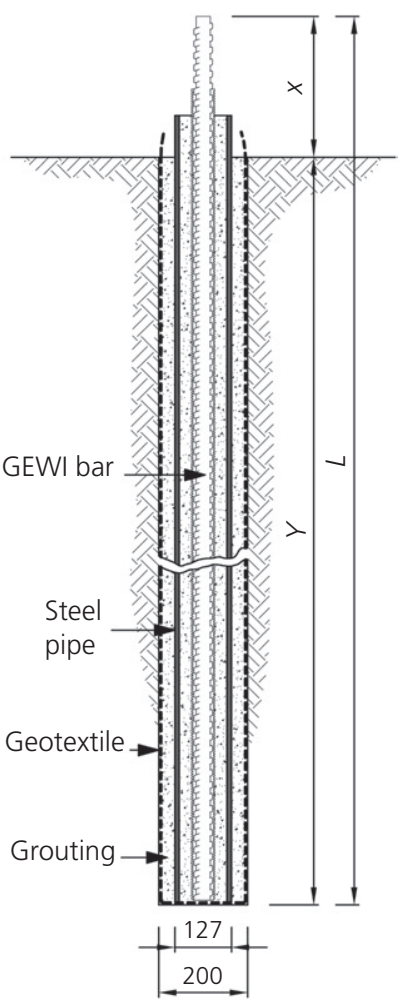

(d) (d) special geotextile-encased micropile T3 tested in tension (dimensions in $\mathrm{mm}$ ) 


\begin{tabular}{lcccc}
\hline Micropile & $L: m$ & $X: m$ & $Y: m$ & $Z: m$ \\
\hline C1 & 6.00 & 0.72 & 5.28 & - \\
C2 & 6.00 & 0.77 & 5.23 & - \\
C3 & 6.00 & 0.81 & 4.50 & 0.69 \\
T1 & 6.00 & 0.72 & 5.28 & - \\
T2 & 6.00 & 0.70 & 5.30 & - \\
T3 & 6.00 & 0.45 & 5.55 & -
\end{tabular}

Table 2. Lengths of boreholes and micropiles installed at the LTS

(Figure 3(c)). Grouting was finally carried out by gravity only, through a tremie pipe lowered to the bottom of the drilled holes. The length $(L)$ of each micropile is reported in Table 2.

In order to measure the individual contribution offered by the base resistance to the overall bearing capacity, a special element (labelled C3) was designed and constructed. In this case, the tubular steel reinforcement was encased with a $4.5 \mathrm{~m}$ long PVC pipe to avoid any possible contact between the surrounding soil and the reinforcement itself. The grout was then introduced by means of a tremie pipe in the tubular reinforcement previously cut at the toe to form the $690 \mathrm{~mm}$ long soil base. After the setting of this first grout, the space inside the tubular reinforcement was filled with additional grout to complete the micropile. Figure 3(b) shows the final construction of special micropile $\mathrm{C} 3$.

Another construction technique sometimes used in granular and permeable soils of the Italian alpine regions is the so-called 'geotextile-encased pile'. The main aim of the geotextile is to prevent any loss of grout that could potentially occur as a result of the high hydraulic soil conductivity often coupled with significant groundwater seepage (i.e. under river or stream beds) or due to the presence of cavities in the zone surrounding the shaft. In particular, under self-weight pressure, the grout tends to press the geotextile towards the wall of the hole, yielding a pile-soil interface characterised by a reduced angle of shearing strength between the geotextile and the coarse soil. In order to investigate this type of micropile, one of the three micropiles tested in tension (labelled T3) was encased with a confining needle-punched non-woven geotextile (Figure 3(d)).

\section{Testing procedure}

Load tests were performed in accordance with the specifications provided by ASTM D1143 (ASTM, 1994) and ASTM D3689 (ASTM, 1995). The reaction frame used for the compression load tests was anchored to two micropiles conceived specifically for this purpose and located at a distance of more than $5 D(1.05 \mathrm{~m})$ from the test micropile. The loads were applied, by means of a hydraulic jack, to the steel tubular reinforcement or to the tendon. The vertical displacement of the head of the tested piles was measured by three dial gauges according to ASTM D1143 (ASTM, 1994).

The loading procedure consisted of the application of increments equal to about $25 \%$ of the pile ultimate load estimated by preliminary computations $\left(Q_{\mathrm{U} \text {,est }}\right)$. Once a load equal to $Q_{\mathrm{U} \text {,est }}$ was applied without the occurrence of failure, the load increments were reduced to $5 \% Q_{\mathrm{U} \text {,est }}$ up to failure of the pile, which is generally associated with the development of relevant displacements (i.e. assumed to be greater than $10 \%$ of the pile diameter $(20 \mathrm{~mm}))$. In this study, load increments of $5 \% Q_{\mathrm{U} \text {,est }}$ were also applied during the loading procedure when unexpected behaviour was observed.

Each load increment was maintained until the displacement rate of the pile head reached $0.008 \mathrm{~mm} / \mathrm{min}$ and, in any case, for a maximum time span of $30 \mathrm{~min}$. Loading-unloading cycles were carried out at different load levels in all tests.

\section{Test results}

Figure 4 presents the load-displacement behaviour from tests under compression and tension loads. In general, the response is characterised by a typical progressive hardening behaviour with the unloading-reloading cycles showing an accumulation of irrecoverable displacements since the very early stages of the tests. Additional features to note are the following.

- The response of micropile $\mathrm{C} 1$ shows a gradual yielding coupled with the development of a relatively small displacement that increases suddenly at a threshold load corresponding to full mobilisation of the shaft friction.

- The compression load test on micropile C2 was interrupted at a load of $450 \mathrm{kN}$ due to alignment problems between the test micropile and the corresponding anchors. The response up to this load was found to be similar to pile $\mathrm{C} 1$. The reported load-displacement curve is incomplete and therefore the test is not included in this study.

- The response of special micropile C3 (designed to mainly measure the contribution offered by the base resistance) is characterised by a highly non-linear load-displacement curve in which large displacements are associated with relatively small load increments. This behaviour is probably due to mobilisation of the shaft friction acting on the lateral surface of the $690 \mathrm{~mm}$ long base (approximately $15 \%$ of the ultimate load estimated using the modified $\beta$ method described later in the paper) together with a progressive increase of the base resistance. Therefore, the assumed load distribution mechanism acting essentially through the pile base seems to be confirmed.

- The load-displacement curves of micropiles T1 and T2 are characterised by an initial stiff response followed by a sudden pull-out, indicating substantially brittle failure of the soil-pile interaction. Despite similar geometry 


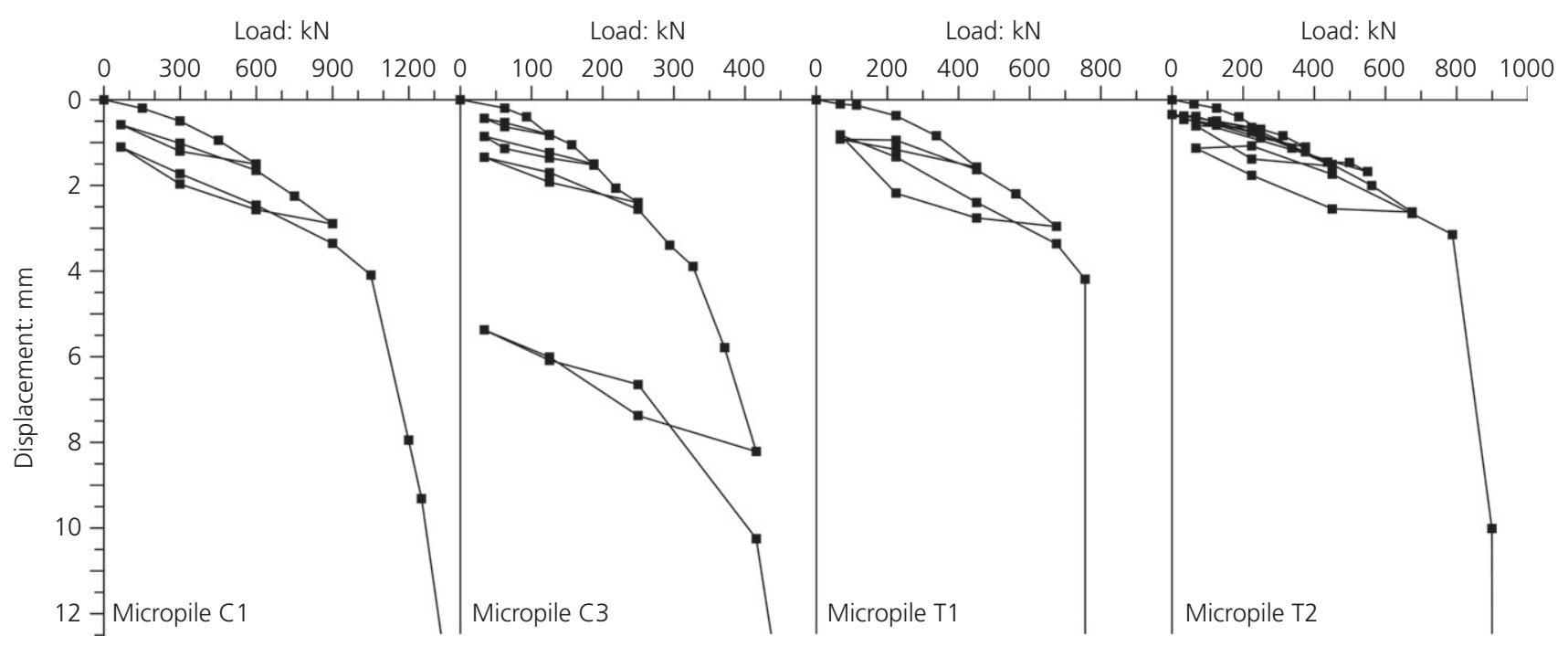

Figure 4. Load-displacement curves from compression and tensile load tests

and subsoil conditions, micropile T2 failed under an axial tension load about $20 \%$ greater than that corresponding to micropile $\mathrm{T} 1$. The reason for this difference is explained in the following sections.

- The behaviour of micropile T3 is very different from those obtained in the other tension tests and is characterised by a marked hardening response with a continuous pull-out of the pile for relatively low load levels. Subsequent extraction of micropile $\mathrm{T} 3$ from the ground showed that a greater part of the shaft encased with the non-woven geotextile was not filled with grout. Hence, the borehole probably collapsed during the installation phase, because of which the annular space between the reinforcement and the geotextile could not be completely filled with grout. For these reasons, micropile T3 will not be considered in the following analysis and discussion.

From the load-displacement curves depicted in Figure 4, the ultimate loads of micropiles $\mathrm{C} 1, \mathrm{C} 3, \mathrm{~T} 1$ and T2 were evaluated. Assuming an ultimate load corresponding to a displacement of the pile head $(w)$ equal to $10 \%$ of the pile diameter (D) (for bored piles, the load at $w / D=0 \cdot 1$ is typically accepted as ultimate load according to EN 1997-1 (CEN, 2004)), the reference ultimate loads $\left(Q_{\mathrm{U}, \text { Test }}\right)$ in both compression and tension were obtained and compared with calculations.

\section{Interpretation of load-displacement curves}

\subsection{Ultimate failure load}

To interpret the experimental load-displacement curves of both groups of micropiles tested in compression and tension, a hyperbolic function was selected according to the relationship
(Chin, 1970)

1. $\frac{w}{Q}=n \cdot w+C$

The results of this procedure are shown in Figure 5 for piles under compression and tension.

The experimental behaviour of the micropiles tested under compression can be described by the Chin hyperbolic model, as shown by the straight line in the $w / Q-w$ plane of Figure 5(a) and by the theoretical $Q-w$ curve overlaying the test data presented in Figure 5(b). More difficulties were encountered in the definition of the hyperbolic parameters related to micropiles $\mathrm{T} 1$ and $\mathrm{T} 2$ due to the sudden pull-out of the piles at failure. Only a few measurements (last two or three experimental points) could be used in this case to obtain the best-fit lines in Figure 5(c) and thus it can be observed in Figure 5(d) that the back-calculated load-displacement curve and the experimental values match poorly, especially at small displacements.

The ultimate load of each micropile $\left(Q_{\mathrm{U}, \mathrm{Chin}}\right)$ could be estimated as the inverse of the slope of the corresponding best-fit lines reported in Figures 5(a) and 5(c). The hyperbolic function normally provides an overestimate of the real ultimate load of piles (Fellenius, 1980). One possible explanation is that the original Chin method does not include any adjustment for elastic deformation of the shaft subjected to vertical load.

According to Hanna (1987), a modified ultimate load ( $\left.Q_{\mathrm{U}, \text { Hanna }}\right)$ can be estimated from the inverse slope of the 


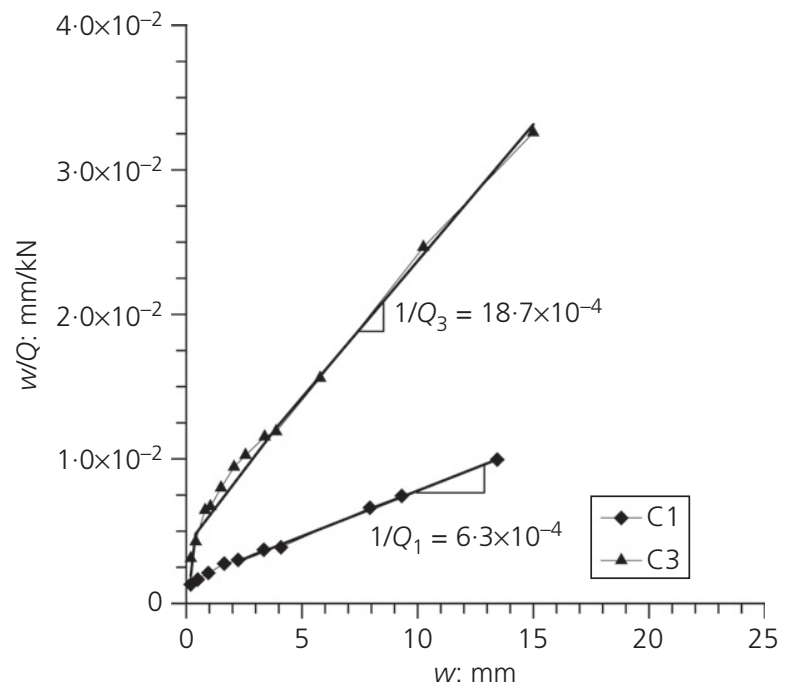

(a)

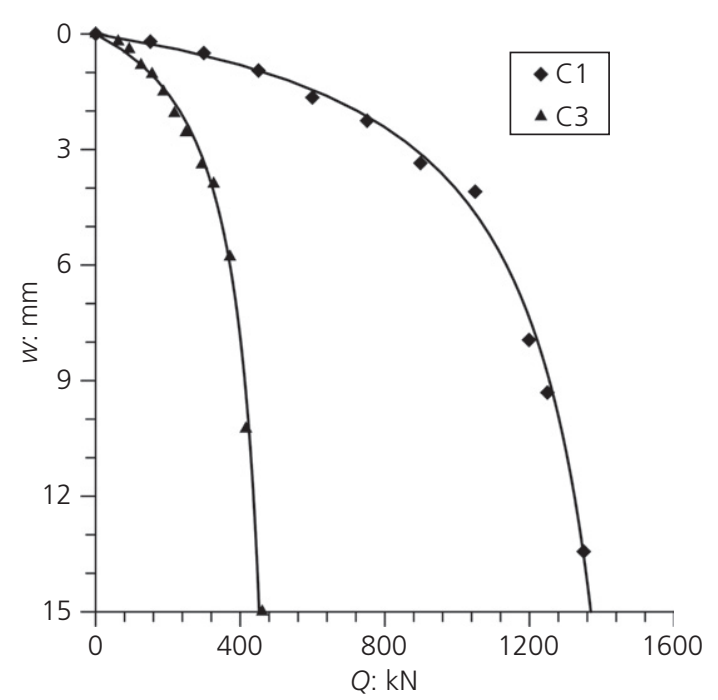

(b)

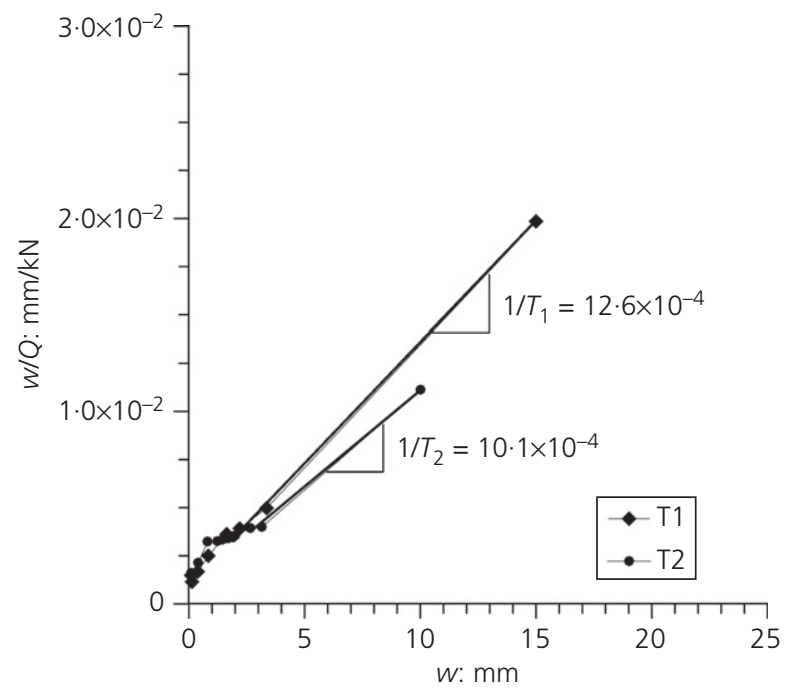

(c)

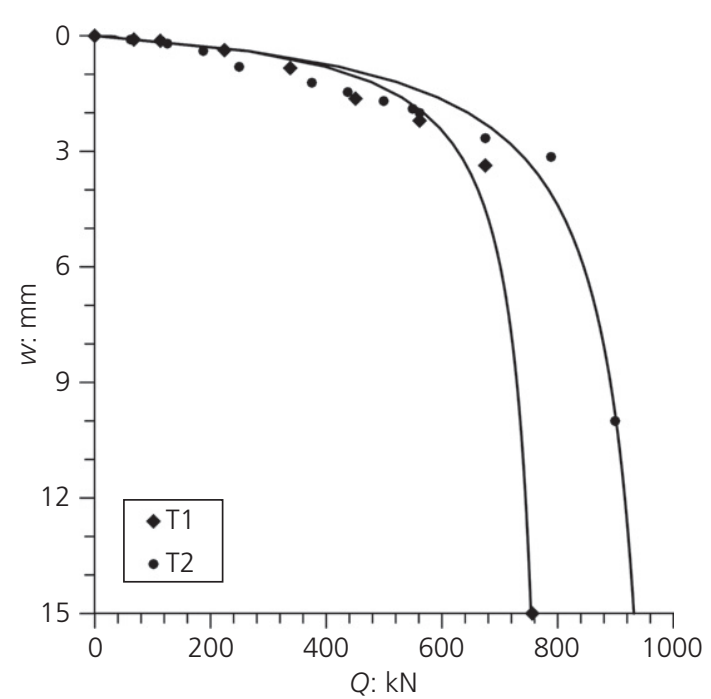

(d)

Figure 5. (a) and (b) Hyperbolic fitting of load tests in compression. (c) and (d) Hyperbolic fitting of load tests in tension

Chin best-fit line in the $w^{\prime} / Q-w^{\prime}$ plane, $w^{\prime}$ being calculated by subtracting the elastic deformation of the shaft from the actual measured displacement. Figure 6 shows good agreement between the measured ultimate loads and the predicted values obtained with the criterion of Hanna (1987) for the micropiles tested under compression and tension, with the difference between measured and predicted values being less than $5 \%$.

In addition to the approach suggested by Hanna (1987), other methods used for interpretation of the experimental loaddisplacement curves of the micropiles in this study are those of Van der Veen (1953), Brinch Hansen (1963), De Beer and Wallays (1972), Fuller and Hoy (1970), Davisson (1972), Butler and Hoy (1977) and Cemset (Fleming, 1992). All these procedures apart from the Cemset method are empirical approaches with no physical basis. A comparison was made between the ultimate loads obtained using these methods and the ultimate failure loads estimated from the in situ load tests. The outcome of this comparison is shown in Figure 7. Generally, for micropiles tested under tension, all the methods provide values in agreement with the field results, with the exception of the methods of De Beer and Wallays and Butler and Hoy, which were considered to be too conservative by Fellenius (1980). For micropiles C1 and C3, tested under compression, an increased variability in ultimate load values is observed, with the methods of De Beer and Wallays, Davisson, and Butler and Hoy being the most conservative. The output provided by the Cemset procedure not only consists of an 
accurate approximation of the real ultimate load, but also of the reconstruction of the entire load-displacement curve for both the shaft friction and end bearing capacity based on a best-fitting of the experimental data. For this reason, Cemset

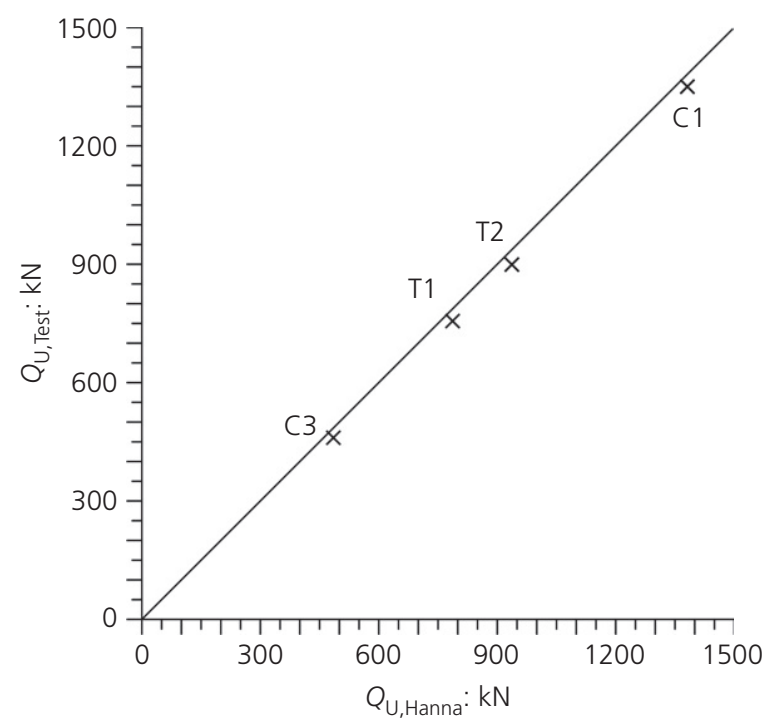

Figure 6. Comparison of ultimate loads obtained directly from load tests and the values estimated using the method of Hanna (1987) was selected as the main back-analysis tool for interpretation of the load-displacement curves resulting from the load tests on the micropiles installed at the LTS.

\subsection{Base resistance}

In geotechnical engineering practice, it is generally assumed that small-diameter bored piles transfer their load to the ground through grout-to-soil shaft friction without any significant contribution from the pile base. This is due to several factors, such as the installation and grouting technique, the greater lateral area compared to the small base area and the necessity of a significant displacement of the base in order to fully mobilise the end bearing capacity (Jeon, 2004; Juran et al., 1999; Russo, 2004; Sabatini et al., 2005; Seo et al., 2013). However, for pile lengths less than $10 \mathrm{~m}$ and for pile bases embedded into dense layers, the load transferred to the base may not be considered negligible (Bellato et al., 2013; Han and Ye, 2006; Misra and Chen, 2004).

Based on back-analysis of the experimental curves of micropiles $\mathrm{C} 1, \mathrm{~T} 2$ and $\mathrm{C} 3$ and assuming a maximum displacement of $2 \mathrm{~mm}$ ( $1 \%$ of the pile diameter) to fully mobilise the shaft resistance, the net load-displacement curve of micropile $\mathrm{C} 1$ could be approximately derived as the sum of those related to micropiles C3 and T2 (Figure 8(a)). In this study, both the developments of the base resistance and the shaft friction are described by hyperbolic functions calibrated on the experimental net load-displacement curves of micropiles C3 and T2. In

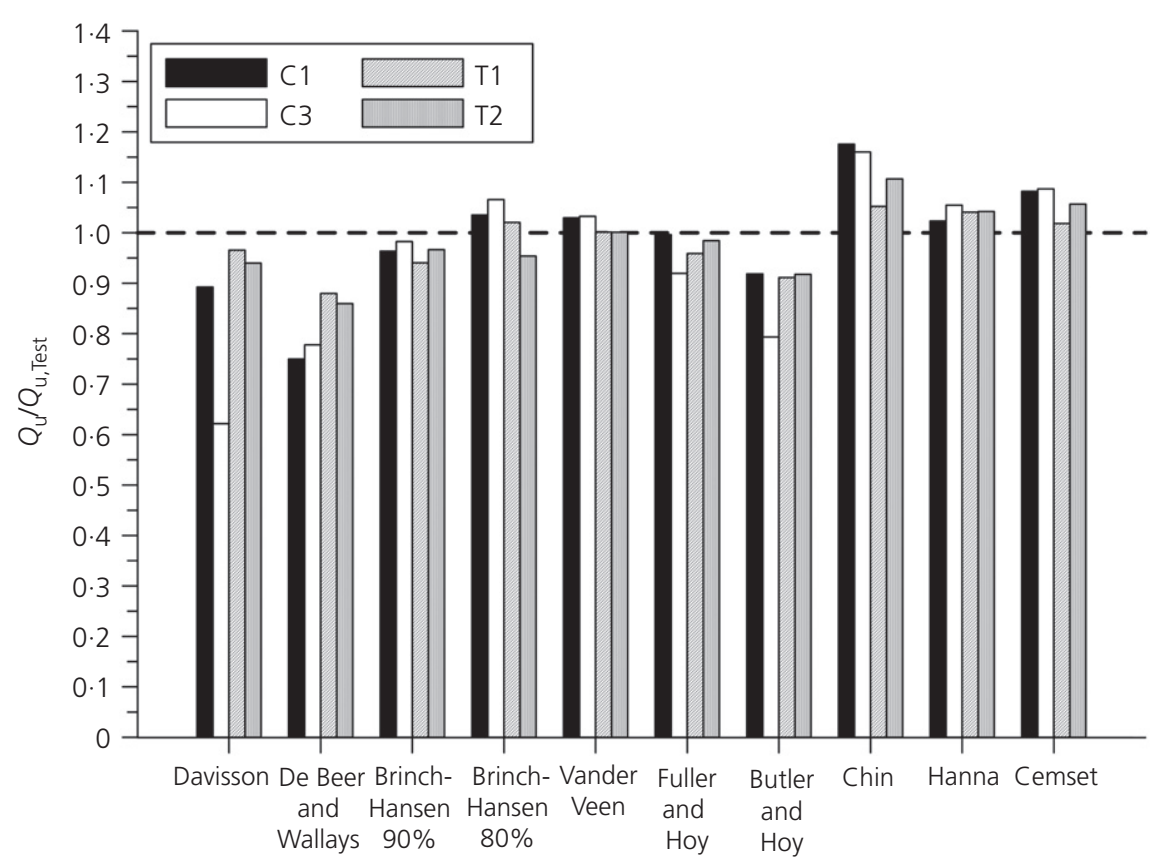

Figure 7. Comparison of ultimate loads obtained directly from pile load tests and values estimated using different methods for the interpretation of load-displacement curves 


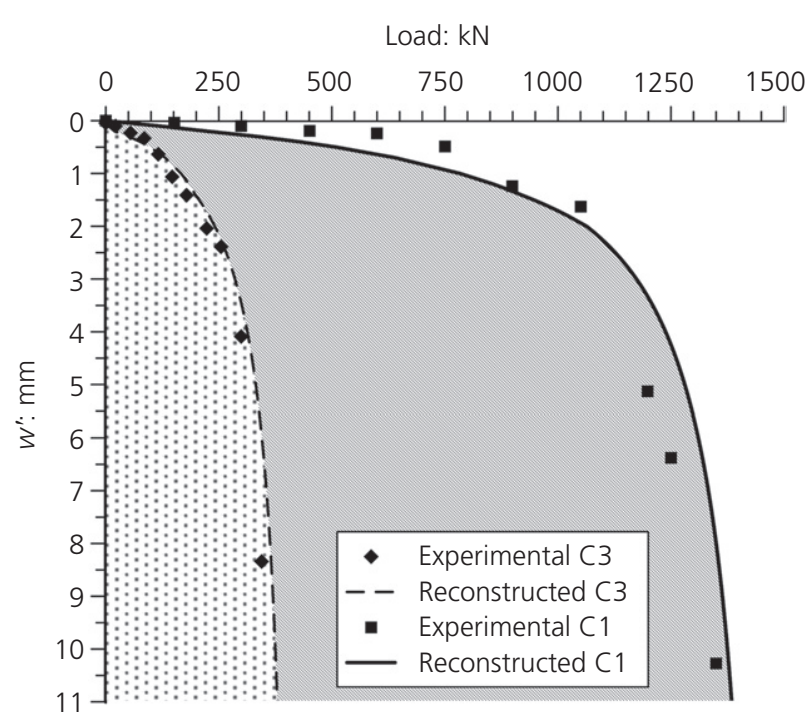

(a)

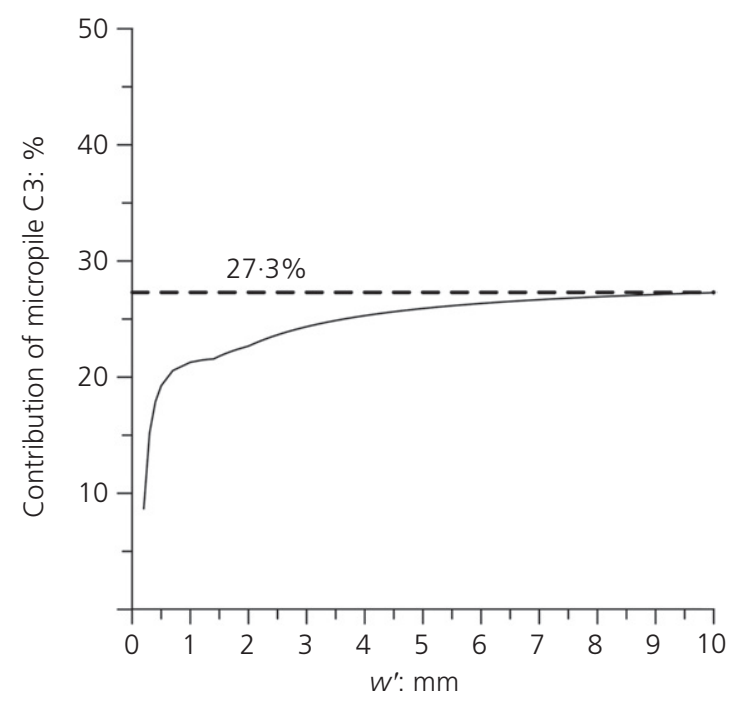

(b)

Figure 8. (a) Reconstruction of the net load-displacement curve of micropile $\mathrm{C} 1$ from those related to micropiles $\mathrm{C} 3$ and $\mathrm{T} 2$.

(b) Contribution of micropile C 3 with respect to the total bearing capacity mobilised by micropile $\mathrm{C} 1$

order to obtain the net load-displacement curve of micropile C1 presented in Figure 8(a), the load axis of the analytical curve relating to micropile $\mathrm{T} 2$ had to be previously rescaled with a factor of $1 \cdot 1$. This load-scaling factor represents the ratio between the shaft resistance mobilised under compression and that mobilised under tension. If micropile $\mathrm{T} 1$ had been used for this analysis instead of micropile T2, the value of this multiplicative coefficient would have been approximately $1 \cdot 3$. The variation range determined in this research $(1 \cdot 1-1 \cdot 3)$ is comparable with values found in similar geotechnical contexts by Bellato et al. (2013) and is in reasonable accordance with the observations of De Nicola and Randolph (1999) and Han and Ye (2006).

Figure 8(b) shows that the base resistance can be gradually mobilised from the beginning of the loading sequence (i.e. after a displacement of less than $1 \mathrm{~mm}$ beyond the elastic shortening of the micropile). The development and final contribution of micropile $\mathrm{C} 3$ with respect to the total mobilised load of micropile $\mathrm{Cl}$ are also shown in Figure 8(b). In particular, the asymptotic value of this contribution is approximately $27 \cdot 3 \%$ of the final ultimate load obtained in this reconstruction. Considering that only a very small proportion of the load of micropile C3 is transferred to the soil through shaft friction, the previous outcome means that more than $20 \%$ of the load of micropile C1 may be directly related to the mobilisation of base resistance. It is important to emphasise that these considerations are especially valid in the case of short micropiles embedded in dense coarse soil layers.

\section{Estimation of ultimate bearing capacity}

Two analytical methods were considered in order to estimate the bearing capacity of the micropiles - the method of Bustamante and Doix (1985) and the commonly used semiempirical methods based on formulae for medium- and largediameter bored piles known as the $\alpha$ method or $\beta$ method as a function of the type of soil surrounding the pile.

As already noted earlier in the paper, a common assumption in the design of small-diameter piles is to neglect the end bearing capacity (Bruce et al., 1997), the base settlement usually not being large enough to fully mobilise the whole base resistance. Taking into account the very rigid response of the coarse soil below the micropile bases at the LTS as well as considering the back-analysis presented in the previous section, a combined mobilisation of shaft and base resistance is assumed in the following calculations.

\subsection{Effective diameter}

A slight increase in the effective pile diameter is normally a reasonable assumption in coarse soils above the groundwater table due to the possibility of a small amount of injected grout seeping from the hole into the surrounding soil. In order to 
determine this increase in diameter, the soil surrounding the piles was excavated at the end of load tests to a depth of about 3-4 m below ground level and then each element was finally pulled out from the ground. Small portions of the shafts corresponding to micropiles $\mathrm{T} 1, \mathrm{~T} 2$ and $\mathrm{C} 3$ were taken from the site and inspected in the laboratory. From an initial visual inspection, pile T2 was characterised by some local protrusions due to the inclusion of gravel particles and cobbles into the grout forming the shaft. On the contrary, pile T1 presented a surprisingly regular and smooth lateral surface. This can be considered the main reason for the difference in terms of ultimate tension load measured during the load tests performed on piles T1 and T2. An intermediate situation was provided by the shape of a portion obtained from the shaft close to the base of micropile $\mathrm{C} 3$, which was scanned using a threedimensional (3D) laser scanner and digitally reconstructed in order to determine more precisely the achieved average increase in diameter. Figure 9(a) shows the reconstruction of the $3 \mathrm{D}$ surface of this shaft portion from micropile $\mathrm{C} 3$ on an imaginary $200 \mathrm{~mm}$ diameter cylinder, representing an ideal shaft. A cylindrical surface corresponding to a larger diameter (equal to $1 \cdot 1 D$ ) is then added in Figure 9(b), showing that the average diameter increase varied generally between $1 \cdot 0 D$ and $1 \cdot 2 D$. Therefore, an effective diameter ranging from $1.0 D$ to $1 \cdot 2 D$ was assumed in the calculations for the different micropiles, according to the visual inspection carried out at the site.

\subsection{Estimate of ultimate bearing capacity of micropiles} The analytical methods used to estimate the bearing capacity of the micropiles installed at the LTS were the method of Bustamante and Doix (1985) and the static formulae commonly used for classical pile design in coarse soils based on the $\beta$ method.

The Bustamante and Doix method completely neglects the end bearing capacity and proposes to calculate the unit shaft

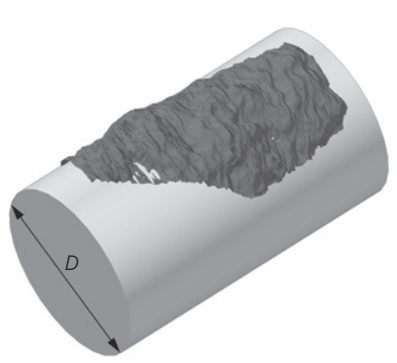

(a)

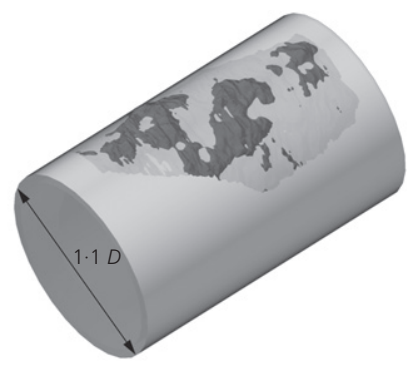

(b)
Figure 9. 3D virtual model of a portion of the shaft from micropile C3 obtained by a 3D laser scanner: (a) reconstructed surface placed on a $200 \mathrm{~mm}$ diameter cylinder (diameter of the borehole, $D$ ); (b) reconstructed surface intersected by a cylinder of diameter $1 \cdot 1 D$ friction mobilised along the shaft as

2. $Q_{\mathrm{u}}=\sum_{i} \pi \cdot D_{\mathrm{s} i} \cdot L_{\mathrm{s} i} \cdot q_{\mathrm{s} i}$

where $D_{\mathrm{s} i}$ is the effective diameter of the pile after the grouting phase, $L_{\mathrm{s} i}$ is the bond length relative to each $i$ th soil layer surrounding the shaft and $q_{\mathrm{s} i}$ is the unit shaft friction mobilised at the soil-pile interface, which is a function of SPT $N$ and the type of pile grouting technique, namely unique global injection (IGU) or repeated and selective injection (IRS). In the subsequent analysis, gravity-filled piles of type A are considered as equivalent to IGU type (type C); that is, as the less efficient of the two types investigated by the authors (Bustamante and Doix, 1985).

In the $\beta$ method, the pile lateral resistance in coarse soils is estimated as

3. $Q_{\mathrm{s}, \mathrm{u}}^{\beta}=\pi \cdot D \cdot \int_{0}^{L} \beta(z) \cdot \sigma_{\mathrm{v}}^{\prime}(z) \mathrm{d} z$

The end bearing capacity in coarse soils can be calculated as

4. $\quad Q_{\mathrm{b}, \mathrm{u}}^{\beta}=\pi \frac{D^{2}}{4}\left(\sigma_{\mathrm{v}, \mathrm{p}}^{\prime} \cdot N_{\mathrm{q}}\right)$

For bored piles, the use of an $N_{\mathrm{q}}$ value according to the formulation of Berezantzev et al. (1961) is often suggested as a practical and conservative approach (Viggiani et al., 2011). Furthermore, to account for possible disturbance of the soil surrounding the pile base due to installation, a modified angle of shearing resistance was used in the computation of $N_{\mathrm{q}}$, as suggested by Poulos and Davis (1980)

\section{5. $\phi_{\mathrm{m}}^{\prime}=\phi^{\prime}-3^{\circ}$}

Considering an effective diameter ranging between $1 \cdot 0 D$ and $1 \cdot 2 D$ (Figure 9(b)), the ultimate bearing capacities of micropiles $\mathrm{C} 1, \mathrm{C} 3, \mathrm{~T} 1$ and T2 installed at the LTS were computed. Neither method provided results in agreement with the failure loads measured during the compression and tension load tests. The discrepancies obtained may be tentatively explained by the following considerations.

Bustamante and Doix (1985) proposed different unit shaft friction curves depending on the type of soil in which the pile is installed and two grouting techniques (IGU and IRS). The authors did not provide any relationship for the construction procedure involving grouting by gravity head only. Despite the assumption of having the same shaft resistance suggested 
for IGU micropiles, an underestimation of the unit shaft resistance was derived. Additionally, since the Bustamante and Doix method completely neglects the base resistance, the total bearing capacity is much lower than that measured in the piles tested under compression.

The $\beta$ method underestimated both the base and the shaft resistance. This may be mainly due to two factors.

Firstly, the suggestion of Poulos and Davis (1980) to modify the angle of shearing resistance according to Equation 5 for the computation of $N_{\mathrm{q}}$ seems to be too conservative in this case because the diameter of the drilling equipment used on site was relatively small compared with the particle size of the soil surrounding the pile base. By using the original angle of shearing resistance estimated from SPTs, an end bearing capacity very close to the experimental value deduced from the interpretation of the load-settlement curve of micropile C3 could be obtained.

Secondly, the equation

6. $\beta_{0}=K_{0} \tan \phi^{\prime}=\left(1-\sin \phi^{\prime}\right) \tan \phi^{\prime}$

considered valid for piles grouted under gravity head only in normally consolidated coarse soils seems to be, in this case, highly conservative in relation to the very rigid response of the ground at the LTS and the mobilised shaft resistance at failure obtained from the tension load tests. For instance, tentatively assuming a uniform shear stress along the whole length of the micropiles and an effective diameter between $1 \cdot 0 D$ and $1 \cdot 2 D$, the average value of $\beta$ was found to be equal to approximately $4 \cdot 37$ (i.e. much greater than the corresponding average value of $\beta_{0} \approx 0 \cdot 3$ ). Even if a horizontal thrust coefficient equal to $1 \cdot 0$ (hydrostatic condition) was assumed, the resulting $\beta$ would have been close to 0.9 (i.e. still much smaller than the value obtained from back-analysis of the test data).

A more suitable approach to estimate $\beta$ for gravelly soils with a percentage of gravel greater than $50 \%$ is that proposed by Rollins et al. (2005)

7. $\beta=3 \cdot 4 \mathrm{e}^{-0.0265 z} \quad 0 \cdot 25 \leq \beta \leq 3 \cdot 0$

An alternative formulation, based on back-analysis of the behaviour of the micropiles at the LTS, is now discussed. The coefficient $\beta$ is obtained using

\section{8. $\beta=K \tan \phi^{\prime}$}

where $K$ is given by

9. $K=K_{0} \exp \left\{I_{\mathrm{D}}\left[4 \cdot 1-\ln \left(\frac{p^{\prime}}{p_{\mathrm{a}}}\right)\right] 1 \cdot 87\left(1-2 K_{0}\right)\right\}$

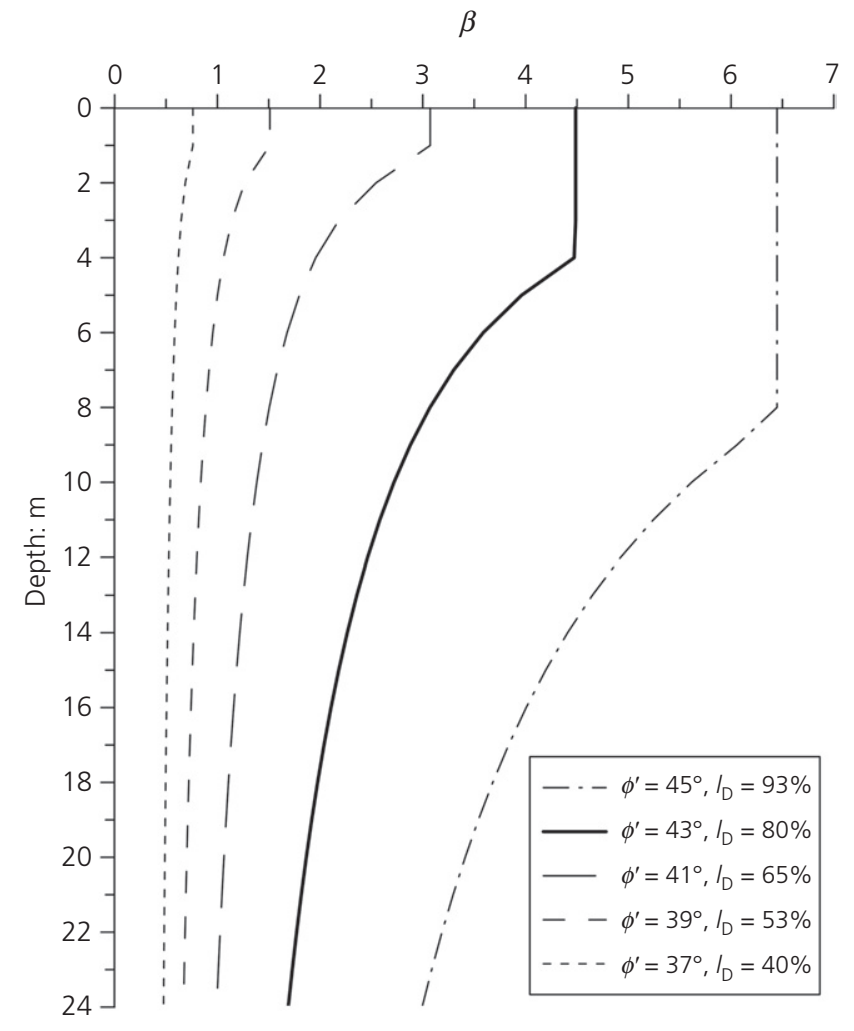

Figure 10. Influence of density index $\left(I_{D}\right)$ and effective peak angle of shearing resistance $\left(\phi^{\prime}\right)$ on $\beta$ coefficient calculated from Equations 8 and 9

The exponential trend of Equation 9 and the dependency of $K$ on the density index, the effective overburden stress and the horizontal earth pressure coefficient at rest were proposed by Loukidis and Salgado (2008) for non-displacement piles in sand based on 1D finite-element analysis coupled with an advanced constitutive model. The term $I_{\mathrm{D}}\left[4 \cdot 1-\ln \left(p^{\prime} / p_{\mathrm{a}}\right)\right] \leq 4$ in Equation 9 is derived from the relative dilatancy index introduced by Bolton (1986). The influence of low confining stresses on the dilatancy of sands has also been recently studied by Chakraborty and Salgado (2010), while revised versions of the relative dilatancy index have been applied by several researchers to study the highly dilatant behaviour of medium-dense to dense sand-gravel mixtures (e.g. Simoni and Houlsby, 2006) or rockfill material (e.g. Xiao et al., 2014). Equation 9 is based on results from back-analysis of the experimental data obtained at the LTS and therefore its use in practical problems involving similar geotechnical contexts requires further verification.

Figure 10 shows the $\beta$ coefficient calculated using Equations 8 and 9 plotted against depth for different values of density index and peak angle of shearing resistance. The figure also shows the depth dependence of $\beta$, with higher values clearly noticeable at shallow depths. As a matter of fact, the soil 


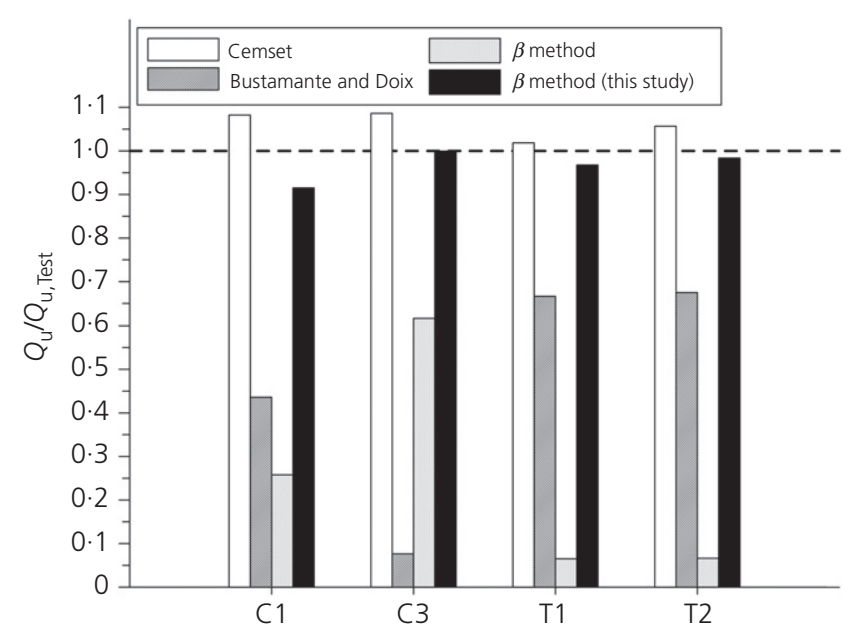

Figure 11. Comparison of ultimate bearing capacities measured during the load tests and those obtained from the methods of Bustamante and Doix (1985) and Cemset (Fleming, 1992), the standard method used for pile design in coarse soil ( $\beta$ method) and the new approach for revised $\beta$

would dilate during shearing near the ground surface with low confining pressure, causing a significant increase in lateral pressure. At greater depth, the increase in lateral pressure is less severe because of a reduced chance of dilation under higher overburden pressures.

Thus, on the basis of the above considerations, the ultimate loads of the micropiles installed at the LTS were recalculated. These new values are compared with the failure loads inferred from the load-displacements curves in Figure 11, which shows a general agreement (within $8 \%$ ) between measured and calculated values.

Figure 12 shows a comparison between the $\beta$ values obtained by using the relationship proposed by Rollins et al. (2005) and the new approach described by Equations 8 and 9 for the dense layer composed of sub-angular and angular shaped sandy gravel with cobbles and boulders encountered at the LTS. From the figure, a reasonable agreement (within 10\%) is found from a depth of about $10 \mathrm{~m}$ below ground level, the $\beta$ values calculated from Equation 7 (Rollins et al., 2005) being progressively smaller at shallower depths.

\section{Conclusions}

The results and interpretation of axial load tests under tension and compression performed on micropiles installed in heterogeneous soils typical of the Italian alpine mountainous area have been presented and discussed.

After preliminary site characterisation carried out by means of in situ and laboratory tests, compression and tension load tests

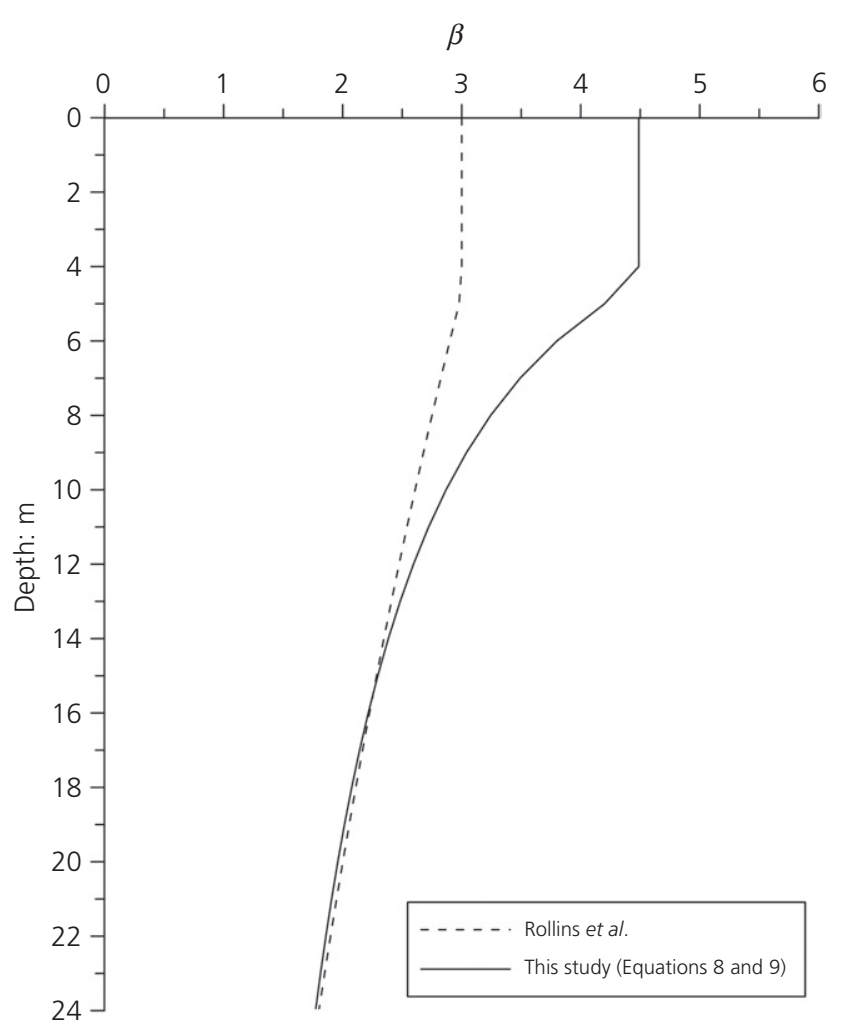

Figure 12. Comparison of the $\beta$ coefficient obtained using Equations 8 and 9 and the formulation proposed by Rollins et al. (2005)

were carried out on gravity-filled micropiles of $200 \mathrm{~mm}$ diameter. After direct extraction of the micropiles from the ground, an increase in diameter up to 1.2 times the original pile diameter was found at the end of the load tests.

Through construction of a special pile with minimised contribution of shaft resistance, a first attempt at interpreting the load distribution between shaft and base resistance was finalised. The results emphasised that the usual assumption of neglecting base resistance in micropile design can be considered too conservative in the case of short micropiles installed in geotechnical contexts characterised by a very rigid mechanical response such as those examined in this work.

The reliability of a number of methods for the interpretation of load-displacement curves obtained from pile load tests was also investigated, proving the reliability of the Cemset approach.

Finally, the outcomes of micropile design based on the relationships introduced by Bustamante and Doix (1985) were compared with the conventional approach customarily adopted for bored pile design in coarse soils (the $\beta$ method) and with the load test results. A significant disparity was found between 
the ultimate loads obtained directly from the load tests and the calculated values. For this reason, a new approach based on the existing $\beta$ method is tentatively suggested in order to better describe the behaviour of micropiles in coarse soils. In this new approach, basic mechanical properties of coarse soils such as dilatancy, density and stress state are considered.

The procedure for the calculation of the bearing capacity of type A micropiles in coarse soils consists of several steps, starting with estimation of the angle of shearing resistance and the density index based on the information available from in situ ground investigations. The peak angle of shearing resistance of the soil surrounding the pile base is used for computation of the factor $N_{\mathrm{q}}$, while the peak angle of shearing resistance of the soil close to the shaft, along with its corresponding density index and the mean overburden effective stress, is introduced in Equations 8 and 9 to obtain $\beta$. Equations 3 and 4 provide the ultimate end bearing capacity and the ultimate bearing capacity due to shaft friction of the micropile, respectively.

The results obtained using this design procedure seem to be promising, showing the relevance of dilative coarse soil response under shear especially at low overburden stress.

\section{REFERENCES}

ASTM (1994) D1143-81: Standard test method for piles under static axial compressive load. ASTM International, West Conshohocken, PA, USA.

ASTM (1995) D3689-90: Standard test method for individual piles under static axial tensile load. ASTM International, West Conshohocken, PA, USA.

Bellato D, D'Agostini S and Simonini P (2013) Interpretation of failure load tests on micropiles in heterogeneous alpine soils. Italian Geotechnical Journal 47(1): 3-16.

Berezantzev VG, Khristoforov V and Golubkov V (1961) Load-bearing capacity and deformation of piled foundation. Proceedings of the 5th ICSMFE, Paris, France. Dunod Editeur, Paris, France, vol. 2, pp. 11-15.

Bolton MD (1986) The strength and dilatancy of sands. Géotechnique 36(1): 65-78.

Brinch Hansen J (1963) Discussion: hyperbolic stress-strain response. Cohesive soils. Journal of the SMFD ASCE 84(4): 241-242.

Brown DA, Turner JP and Castelli RJ (2010) Drilled Shafts: Construction Procedures and LRFD Design Methods. Federal Highway AdministrationWashington, DC, USA, FHWA-NHI-10-016.

Bruce DA, Di Millio AF and Juran I (1997) Micropiles: the state of practice. Part 1: characteristics, definitions and classifications. Ground Improvement 1(1): 25-35.

Bustamante M and Doix B (1985) Une méthode pour le calcul des tyrants et des micropieux injectées. Bulletin des Liaison Laboratoire des Ponts et Chaussées 140: 75-92 (in French).
Butler HD and Hoy HE (1977) User Manual for the Texas Quick-Load Method for Foundation Load Testing. FHWA, Washington, DC, USA.

CEN (European Committee for Standardization) (2004) EN 1997-1: Eurocode 7: Part 1 (2004): Geotechnical design, general rules. CEN, Brussels, Belgium.

CEN (2007) EN 1997-2: Eurocode 7: Part 2 (2007): Ground investigation and testing. CEN, Brussels, Belgium.

Chakraborty T and Salgado R (2010) Dilatancy and shear strength of sand at low confining pressures. Journal of Geotechnical and Geoenvironmental Engineering 136(3): 527-532.

Chin FK (1970) Estimation of the ultimate load of piles not carried to failure. Proceedings of 2 nd Southeast Asian Conference on Soil Engineering, Singapore. Balkema, Rotterdam, the Netherlands, pp. 81-90.

Davisson MT (1972) High capacity piles. ASCE Lecture Series, Innovations in Foundation Construction. ASCE, St. Charles, IL, USA, pp. 81-112.

De Beer EE and Wallays M (1972) Franki piles with overexpanded bases. La Technique des Travaux 333: $1-48$.

De Nicola A and Randolph MF (1999) Centrifuge modeling of pipe piles in sand under axial loads. Géotechnique 49(3): 295-318.

Fellenius BH (1980) The analysis of results from routine pile load tests. Ground Engineering 13(6): 19-31.

Fleming WGK (1992) A new method for single pile settlement prediction and analysis. Géotechnique 42(3): 411-425.

Fuller RM and Hoy HE (1970) Pile load tests including quick-load test method, conventional methods and interpretations. Highway Research Record 333: 74-86.

Han J and Ye SL (2006) A field study on the behaviour of micropiles in clay under compression or tension. Canadian Geotechnical Journal 43(1): 19-29.

Hanna TH (1987) Ground anchorages: ultimate load estimation by the Chin method. Proceedings of the Institution of Civil Engineers Part 1 82(3): 601-605.

Hong WP and Chim N (2015) Prediction of uplift capacity of a micropile embedded in soil. KSCE Journal of Civil Engineering 19(1): 116-126.

Jeon SS (2004) Interpretation of load tests on minipiles. Proceedings of the Institution of Civil Engineers Geotechnical Engineering 157(2): 85-90, http://dx.doi.org/ 10.1680/geng.2004.157.2.85.

Juran I, Benslimane A and Bruce DA (1996) Slope stabilization by micropile reinforcement. Landslides 5: 1718-1726.

Juran I, Bruce DA, DiMillio A and Benslimane A (1999) Micropiles: the state of practice. Part 2: design of single micropiles and groups and networks of micropiles. Ground Improvement 3(3): 89-110.

Larsson K and Jog D (2014) Performance of micropiles used to underpin highway bridges. Journal of Performance of Constructed Facilities ASCE 28(3): 592-607. 
Loukidis D and Salgado R (2008) Analysis of the shaft resistance of non-displacement piles in sand. Géotechnique 58(4): 283-296.

Misra A and Chen CH (2004) Analytical solution for micropile design under tension and compression. Geotechnical and Geological Engineering 22(2): 199-225.

Misra A, Chen CH, Oberoi R and Kleiber A (2004) Simplified analysis method for micropile pullout behavior. Journal of Geotechnical and Geoenvironmental Engineering ASCE 130(10): 1024-1033.

Misra A, Roberts LA, Oberoi R and Chen CH (2007) Uncertainty analysis of micropile pullout based upon load test results. Journal of Geotechnical and Geoenvironmental Engineering ASCE 133(8): 1017-1025.

Poulos HG and Davis EH (1980) Pile Foundation Analysis and Design. Wiley, New York, NY, USA.

Rollins KM, Clayton RJ, Mikesell RC and Blaise BC (2005) Drilled shaft side friction in gravelly soils. Journal of Geotechnical and Geoenvironmental Engineering ASCE 131(8): 987-1003.

Russo G (2004) Full-scale load tests on instrumented micropiles. Proceedings of the Institution of Civil Engineers - Geotechnical Engineering 157(3): 127-135, http://dx.doi.org/10.1680/geng.2004.157.3.127.

Sabatini PJ, Tanyu B, Armour T, Groneck P and Keeley J (2005) Micropile Design and Construction - Reference Manual. Federal Highway Administration, Washington, DC, USA, FHWA-NHI-05-039.
Schanz T and Vermeer PA (1996) Angles of friction and dilatancy of sand. Géotechnique 46(1): 145-151.

Seo H, Prezzi M and Salgado R (2013) Instrumented static load test on rock-socketed micropile. Journal of Geotechnical and Geoenvironmental Engineering ASCE 139(12): 2037-2047.

Simoni A and Houlsby G (2006) The direct shear strength and dilatancy of sand-gravel mixtures. Geotechnical and Geological Engineering 24(3): 523-549.

Van der Veen C (1953) The bearing capacity of a pile. Proceedings of the 3rd ICSMFE, Zurich, Switzerland. Organization Committee ICOSOMEF, Zurich, Switzerland, vol. 2, pp. 84-90.

Viggiani C, Mandolini A and Russo G (2011) Piles and Pile Foundations. Spon Press, Abingdon, UK.

Xiao Y, Hanlong L, Chen Y and Chu J (2014) Influence of intermediate principal stress on the strength and dilatancy behavior of rockfill material. Journal of Geotechnical and Geoenvironmental Engineering 140(11).

Yoshida Y, Ikemi M and Kokusho Y (1988) Empirical formulas of SPT blow-counts for gravelly soils. Proceedings of the 1st International Symposium on Penetration Testing ISOPT-I, Orlando, FL, USA. Balkema, Rotterdam, the Netherlands, pp. 381-387.

Ziaie Moayed R and Naeini SA (2012) Improvement of loose sandy soil deposits using micropiles. KSCE Journal of Civil Engineering 16(3): 334-340.

To discuss this paper, please email up to 500 words to the editor at journals@ice.org.uk. Your contribution will be forwarded to the author(s) for a reply and, if considered appropriate by the editorial panel, will be published as discussion in a future issue of the journal.

Proceedings journals rely entirely on contributions sent in by civil engineering professionals, academics and students. Papers should be 2000-5000 words long (briefing papers should be 1000-2000 words long), with adequate illustrations and references. You can submit your paper online via www.icevirtuallibrary.com/content/journals, where you will also find detailed author guidelines. 